\title{
Analysis of Damage Incurred in Nine Months and Investigating Restoration Methods of Old Buildings in the Historic Texture of Tabriz Bazaar (Case Study: Shahidi-Rasta-Bazari)
}

\author{
Panteha HOSSEINISHIRAZI* \\ B.A. of Architectural Engineering, Islamic Azad University, Tabriz, Iran \\ *Corresponding author: Pantea.hsh@gmail.com
}

\begin{abstract}
The main aim of this research is to identify the worn and historic places of the Tabriz Bazaar that as a result, it identifies the type of the texture of Corridor including the historicity of the texture and other factors. Accordingly, architectural restoration is a branch of architecture which is based on identification and studying the historic texture and buildings and leads to the restoration of historic spaces in terms of structural and functional aspects. The buildings in the texture are important in terms of authentication and manifestation of beliefs, cultures, behaviors and social relations. The main goal of this research is to offer an appropriate strategic design for organization and better performance of the old and historic texture of Tabriz Bazaar. Tabriz Bazaar, with an area of about one $\mathrm{km}^{2}$, is the biggest covered traditional bazaar in the world. This bazaar was restored by the last governor of Tabriz, Najafgoli Khan Danbali, three centuries ago and after the earthquake in $1193 \mathrm{AH}$. Restoration of the market malls can be effective in the preservation and restoration of the historic fabric and the building structural life as full potential spaces in the cities in the form of structural strategic design and its connection to the texture. In the historical context of the Tabriz bazaar as a national capital (material and spiritual), there are several active and semi-active Serai. This research investigates the building. Examines the complications that have been caused problems and probable solutions and then proposes the texture restoration design according to the spatial and structural capabilities and a correct practical definition of the monument has been suggested. The goal is meet the needs of the community and changing the perception of the inhabitants of the texture of the old buildings, it also provided protection for the building. The final design consists of a macro-to-small solution, Due to the location of valuable buildings in the old Tabriz texture, Particularly valuable corridors in the historical context of the bazaar have been tried first by introducing the scope and importance of conservation and restoration, identifying and examining the materials used in these historical buildings, Their purposefulness, familiarity with Shahidi-RastaBazari, and the pathology and technology of this building, and ultimately provide the new protective and protective methods that are the main objectives of the project. The research method was applied in terms of goal and descriptive and analytical in terms of methodology and the data were collected through library and field method and the data were analyzed qualitatively.
\end{abstract}

Keywords: historical value, old texture, destruction process, protection, new solutions, protection and restoration of historic buildings, Tabriz Bazaar, restoration

Cite This Article: Panteha HOSSEINISHIRAZI, "Analysis of Damage Incurred in Nine Months and Investigating Restoration Methods of Old Buildings in the Historic Texture of Tabriz Bazaar (Case Study: Shahidi-Rasta-Bazari).” American Journal of Civil Engineering and Architecture, vol. 5, no. 6 (2017): 225-236. doi: 10.12691/ajcea-5-6-2.

\section{Introduction}

Tabriz Bazaar, with an area of one $\mathrm{km}^{2}$, is the biggest covered traditional bazaar in the world and it was registered in August 2010 as the first marketplace in the list of UNESCO World Heritage [4].

The factors, including the bazaar architectural style, shop`s arrangement, multiplicity of timche (arcades), caravansaries, corridors, halls, rows and also the types of businesses and professions, historic schools and mosques, have converted this bazaar to an outstanding example of a trading place with Islamic and eastern lifestyle. Tabriz Bazaar is a multi-axis wide area network with paralleled or crossed rows including small markets and halls. This part of the city represents the cultural, economic and social dimensions of the people who have lived in this part in different periods and recorded its cultural identity. Thus, protection, restoration and regeneration of this texture and its adoption with urban system can improve the historic area life along with the progress of the city [4]. 
Natural disasters, which threaten Tabriz Bazaar, demand a broad scope of measures and criteria rooted in the art, architecture, culture and customs. Repairers are people who make a bridge between the past and future architecture so that they establish future by the past experiences and use their knowledge, information and academic experiences in restoration by identifying the priorities and having essential plans for the organization and survival of the historic buildings [4].

Historic restoration is indeed the restoration of the valuable historical and cultural buildings that have been destructed or severely damaged. The fundamental and structural restoration is converting to the primary state, historical simulation and maximum restoration and minimum regeneration. Although coping with rapid changes is not easy, but via studying and analysis of premodern architecture and urban building, the forgotten cultural, economic, social and ethical advantages can be represented and introduced [4].

The ability to encounter with ever-increasing challenges of these buildings which is affected by time, technology, economic, politics and etc. is one of the management solutions that converts the challenges to opportunities. The minimum advantage of these efforts is the preservation of the heritages and providing more choices for the next generation. Iran's traditional bazaars are one of the appropriate examples for representing the Iranian architectural advantages; examples of the joyful and the multidimensional lifestyle of Iranian which makes a deep connection between social, economic, cultural, belief, ethical and family area [4].

The challenges in the structure, architecture, landscape, economy, society and culture alongside with several hundred years efforts is a dynamic visualization of the thoughts, cultures and ideals of the Tabriz Bazaar complex with ups and downs in history and locating in the top agenda of various governments and according to lack of trust between the marketers and the government, this complex could establish a deep connection with thoughts flowed among 8000 shops. This article tries to explain the problems of Tabriz Bazaar, the challenges and the initiatives of the World Heritage Organization of Tabriz Bazaar for solving the problems and also preventing probable damages [2].

Raste-Bazaar is one of the biggest area of Tabriz Bazaar. There are different rows and corridors in which the required products are sold so that it is called "national bazaar". One of the most important row of Raste-Bazaar is ShahidiRasta-Bazari. It has a entrance hall with covered corridors with beautiful brick domes which is considered as one of the most valuable and oldest historical markets. The aim of this article is to introduce these markets and investigate them that is possible via visual and structural identification. To do this, field studies, regional studies, investigation of their damages have been carried out and new solutions have been proposed for prevention of damages [2].

\section{Location and Specifications of the Tabriz Bazaar Area}

Tabriz Bazaar is one of the biggest and important covered bazaars in Iran and Asia. This bazaar, with an area of one $\mathrm{km}^{2}$, is the biggest covered marketplace in the world. It was registered on the UNESCO World Heritage list in August 2010. This bazaar consists of numerous subparts, corridors, arcades and caravansaries. Tabriz and Tabriz Bazaar were important due to locating Tabriz on the Silk Road and passing of different Asian, African and European caravans.

It was restored by the time governor of Tabriz, Najafgoli Khan Danbali, three centuries ago and after the earthquake in $1193 \mathrm{AH}$. It was registered on the Iran national heritage list in 1975. The date of construction of this site is unknown; however, most of the tourists who visited this site from the fourth century $\mathrm{AH}$ to Qajar period have offered information about it. This part of the city has experienced specific cultural, political and economic situations and bears the traces of the historic periods' cultural identity. These buildings and works reflect the historic identity of this city and protection of these valuable cultural heritages requires identification of the effective components [1].

Most of the tourists such as Ibn Batoteh, Marco Polo, Jacobsen, Ovliyaei Chalabi, Yagut Hamavi, Gasper Doraville, Alexis Soketov, Jean Chardin, Jean Flandin, John Cartwright, Clavijo, Robert Watson, Hamdollah Mostofi and Mogadasi described the glory of Tabriz Bazaar. Having about 5500 shops and 400 jobs, 35 halls, 25 arcades, 30 mosques, 20 raste and raste bazaar, 11 corridors, 5 baths, 12 schools, this bazaar is considered as the main trading center in Iran and Tabriz. The oldest map of Tabriz dates back to 940 AH drawn by Matragchi and it is held in a museum in Turkey [1].

Due to being located in the residential fabric in the most Iranian cities, bazaars can lead to the development of the city. Tabriz is not exceptional in this regard and the main texture of Tabriz Bazaar consists of two covered parts: north-south and east-west parts. The main entrance of Tabriz Bazaar is currently located at the north end of Ferdosi Street. Tabriz Bazaar is considered as the heart of the city and it plays a main role in the city texture. This bazaar ends in princes' palaces in east, Jameh Mosque in west and it includes some parts of Mehran River in north and these sections are connected to each other by wooden bridges located in the direction of the rastas [4].

The first map of Tabriz bazaar was drawn by Asadalluah Maraghei in $1327 \mathrm{AH}$ as a part of the Tabriz Dar al-Saltanah map. It was drawn in the northeast of the map and most of the important places, Like timche and caravansaries, were named on this map. The width ranges from four to five meters and the height is five to six meters shorter than the other bazaars in the hot regions of Iran [1].

Hamdollah Mostofi, the famous historian and geographer of the sixth century, has referred to abundance of fruits and grains in Tabriz, advantages of some fruits such as pear, apple, apricot and grapes and introduced the people of Tabriz whether poor or wealthy as traders and he has mentioned that there are many rich people. In Abass Mirza period, many halls and bazaars were constructed in Tabriz which was Dar el Saltanah [4].

In 1949, Huthem Schindler writes about Tabriz and its Bazaars as follows:

It is a big city and probably is superior to Tehran in this term. Its markets and bazaars are bigger and more 
beautiful than Tehran bazaars. Regardless of the financial transactions and payment facilities that Tehran has superiority, Tabriz is indeed a real trading center of Iran. Although it is located in the farthest part of north-west, it is influential in all over Iran [3,4].

Jean Unire, the French tourist writes:

In the past, Tabriz was more modern than Tehran and this is normal since Ardebil in Azerbaijan province was chosen as the Capital of Iran in Shah Abass period and Tabriz was attached by Ottomans due to its specific situation and adjacency to Ottomans borders. However, due to the proximity of this region and being located on the Silk Road, it had a close relationship with Ottomans and trading with European countries. Hence, bazaars played a major role in Tabriz trading situations. For this reason, different countries' currencies, like Duca, Venice, Lire and Ruble, were exchanged in Tabriz Bazaar. Timche Amir is one of the masterpieces of Tabriz Bazaar architecture. Mirza Mohammad Khan Amir Nezam Zanganeh constructed this section and he died in $1260 \mathrm{AH}$. The architect of this monument was Samad whose story is famous among Tabriz architects. He lived in poverty in his late life [2].

Iranian bazaars are independent complexes consisting of shops, arcades, caravansaries, squares, religious buildings, baths and other public places. This traditional trading center usually has brick arched vault. The Iranian bazaars are mostly linear. The other sections of the bazaars, such as retailers and corridors, have been shaped in different periods. The word of bazaar is rooted in Pahlavi "vachar" and is still used in Gilan and Natanz (Iranian cities) and the word of "bazaargan" (merchant) roots in this word.

This word entered in Portuguese and then in France and English due to trading between Iranians and Portuguese so that they also called "market" their place of purchase. During the formation of bazaar in Iranian cities, various elements appeared as the main and secondary components based on culture, climate and governing style. Rapid growth and progress of Tehran caused chaos in the bazaar's traditional architecture so that many sections of the bazaar were restored or renewed and the proportionality among the different parts was lost $[7,8]$.

\subsection{Introduction of Various Market Parts}

\subsubsection{Raste}

Rasta and the big markets of Tabriz are covered-corridor which do not have entrance and they act as the main passages of the bazaar. The most important rastas are New Rasta Bazari, Old Rasta Bazari, Shahidi Rasta Bazari, Bashmakhchi bazari, Safi Bazari, Imam-Juma mosque Rasta, Gizbasdi Bazari, Burkchu Bazar, Sadigiyya Rasta Bazari, Yamanduzan Bazari, Sarraja Bazar, Panbikh-chi Bazari, Shishegar khana bazari, amir-bazarinin-dalisi (Beiglarbeigi Bazaar), Davachi Bazarchasi (Shotorban) and Karanei-khana Bazarchasi [7,8].

\subsubsection{Dalan (Corridor)}

The halls, arcades and caravansaries are connected to the main bazaar by corridors and they are mostly famous for the connected arcades and halls from whom the most famous halls are Ganni Dalani, Haj-Ali-Akbar dalani, Mirza-Mammad Dalani, Haj-Sheykh dalani, Birinji-HajAbulqasim dalani and Ikinji-Haj-Abulqasim $[7,8]$.

\subsubsection{Timche (Arcade)}

Timche is a space and area that whose ceiling was constructed as a dome with brickwork in the specific historic style. They have a big and strong entrance that they are open during the day and closed at nights and holidays. There are guardians in each timche who are called "Odabashi” or watchman. Arcades are divided into four sections in terms of usage; the public place of timche is used as warehouses; underground is used for storing the goods, the shop in the first floor is used for social and economic affairs. The second floor was used for resting and the foreign merchants stayed there at nights in the past $[7,8]$.

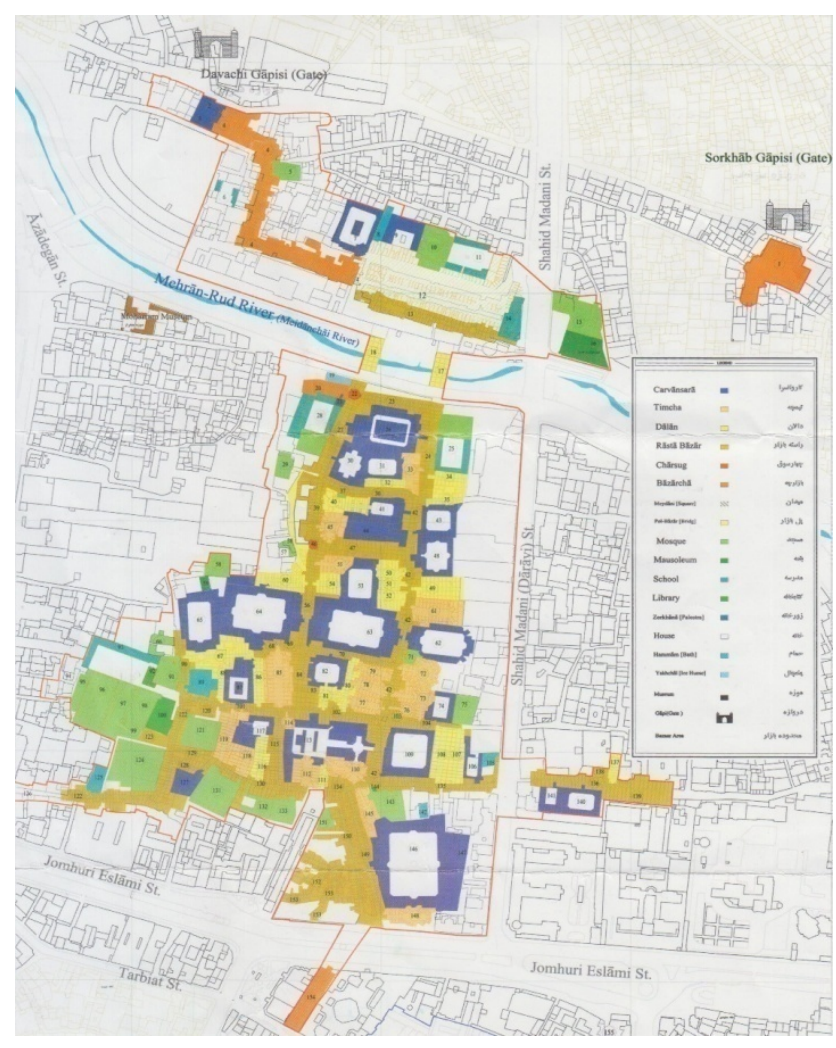

Figure 1. Tabriz Bazaar situation and district

\subsubsection{Caravansara and Sara}

In the past, the owners of the caravans brought their goods and animals into the yard of the caravansara. There were numerous rooms, shops and warehouses around the caravansara that were considered a place for trading. The yards included green spaces, pools and cistern. These spaces acted as green space and garden that provided fresh air via the holes in the domes. The important Saras in the Tabriz bazaar were small units with open yards smaller that caravansara. In the past, the goods carried without animals were discharged in these places $[7,8]$.

\subsection{Situation and Specification of New Raste Bazaar}

This raste is the biggest and the longest spatial pattern in the bazaar. According to this fact that the structure of 
this raste has been shaped gradually by irregular connection of the shops to each other, thus this path is deviated in some areas. However, the length of this raste is about three hundred and thirteen meters that ends to Shahid Gazi tomb in south in the intersection of the shoemakers' raste and ends to Mirza Shafie timche in the north. The slope of the new raste bazaar is from south to north with some irregularities in the path. The shops do not have the same dimensions and their areas are significantly different [2].

Some of the shops are on the same level with the bazaar and some others are upper or lower than the bazaar level.
In addition to the main trading space, some of the shops possess a space in their back area that is used as a private area or warehouse. Perhaps the most complete section of the bazaar is this section in terms of diversity of jobs and goods. These jobs include carpet and rug shops, clothes shops, towel shops, wholesaler, decorative devices, band and so on. The ceiling was constructed as vault that provides a calm and secure place for buyers and standing in front of the shops. Various types of vault, including kejaveh, charbakhshi and etc. can be seen in this section [2].

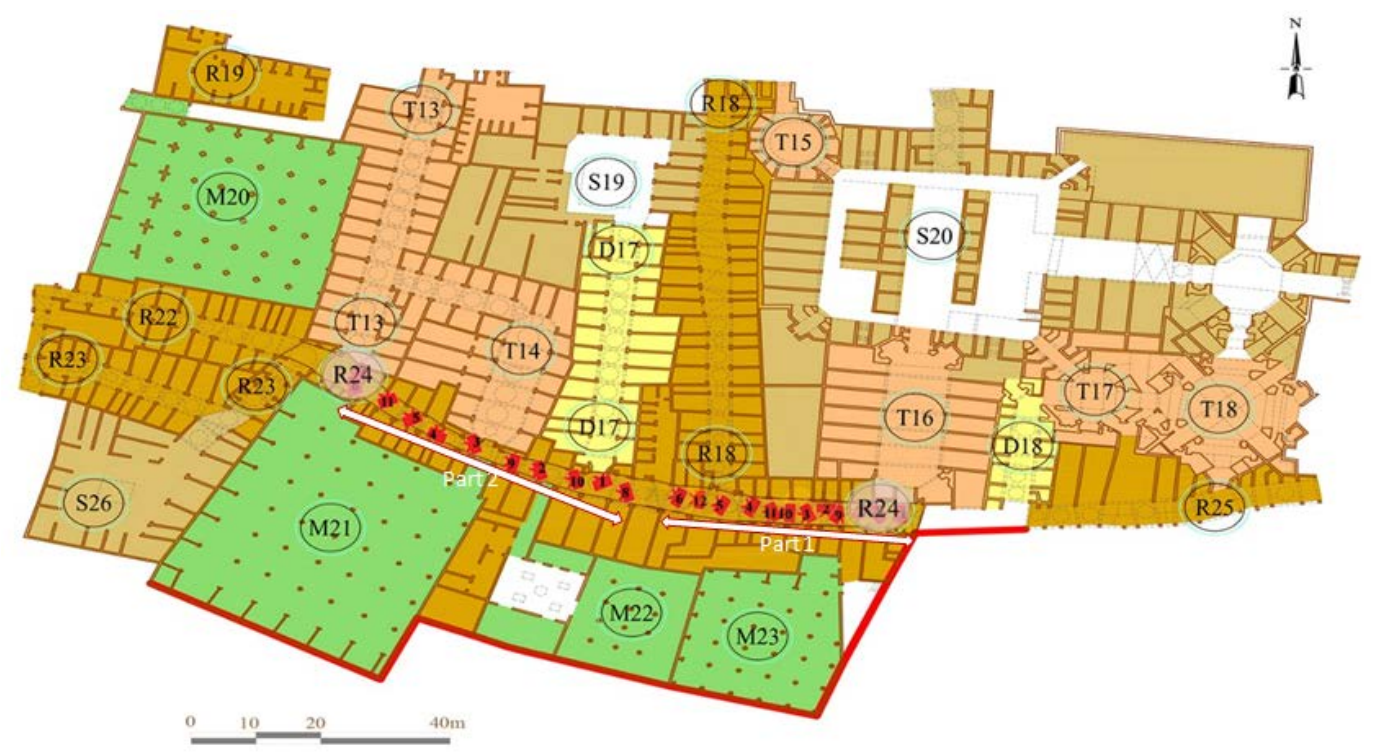

Figure 2. Situation and district of Shahidi-Rasta-Bazari (R24: situation and district of Shahidi-Rasta-Bazari, Part1-Camera1-11 and Part2-Camera1-11: You will see images on the following pages)

\section{The Problems of the Marketers and Users of the Space}

Table 1. Problems and proposed solutions of workers and users of space $[5,6]$

\begin{tabular}{|l|l|}
\hline Problems & Recommendations and Solutions \\
\hline $\begin{array}{l}\text { Visual chaos and inappropriate } \\
\text { view }\end{array}$ & $\begin{array}{l}\text { Structural reformation alongside } \\
\text { with renovation and restoration }\end{array}$ \\
\hline Visual chose in the facade & $\begin{array}{l}\text { Using traditional methods in } \\
\text { renovation }\end{array}$ \\
\hline $\begin{array}{l}\text { Instability in incidents and high } \\
\text { risk structures }\end{array}$ & Strengthening the structure \\
\hline $\begin{array}{l}\text { Wearing out the shops and non } \\
\text { standard and irregular construction }\end{array}$ & $\begin{array}{l}\text { Removing the extra elements and } \\
\text { harmony between shops }\end{array}$ \\
\hline $\begin{array}{l}\text { Low quality of environment and } \\
\text { environmental pollution in the } \\
\text { passages }\end{array}$ & $\begin{array}{l}\text { Establishing appropriate flooring } \\
\text { in the passages }\end{array}$ \\
\hline $\begin{array}{l}\text { Missing of the artistic and historic } \\
\text { values }\end{array}$ & $\begin{array}{l}\text { Preservation and restoration of } \\
\text { the artistic and historic values }\end{array}$ \\
\hline $\begin{array}{l}\text { Lack of essential services and } \\
\text { equipment and having the old and } \\
\text { non-standard installations }\end{array}$ & $\begin{array}{l}\text { Removing factors causing visual } \\
\text { chaos }\end{array}$ \\
\hline
\end{tabular}

\section{Damages}

Any destructive factor causing imbalance in the building and its values is called "damage”. In other words, the building damage is seen in the visible section of the building with factors such as cracks, humidity, appearance changes in the paint and resistance of the materials [8].

\subsection{Visual Damages}

The building experiences visual damage, inappropriate view, low environmental quality and environmental pollutions in the passages and the visual chaos is seen in the façade. The shops' wearing out condition leads to loosing the artistic and historical values and the installations and signs [9].

\subsubsection{Comparison of Damages in Nine Month}

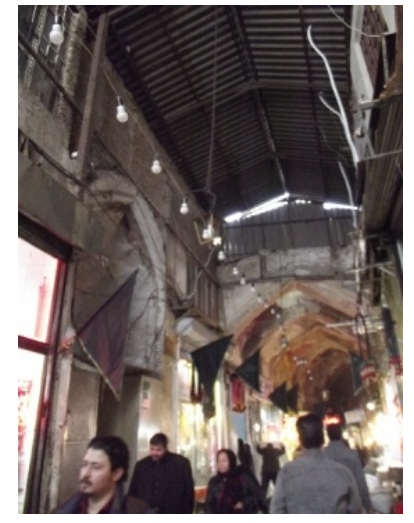

Figure 3. Part 1-Camera 1: Shahidi-Rasta-Bazari 03/2016 


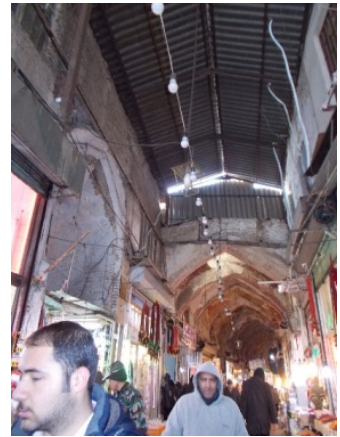

Figure 4. Part 1-Camera 1: Shahidi-Rasta-Bazari 11/2017

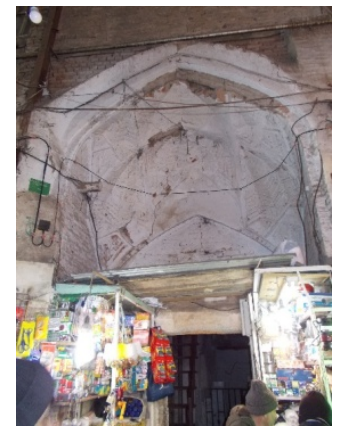

Figure 5. Part 1-Camera 2: Shahidi-Rasta-Bazari 03/2016

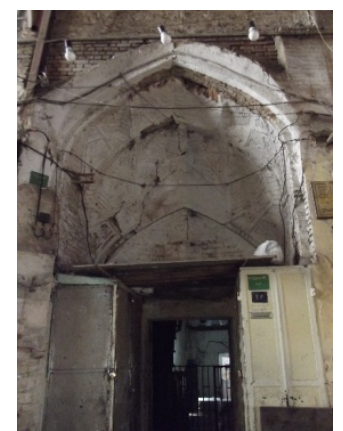

Figure 6. Part 1-Camera 2: Shahidi-Rasta-Bazari 11/2017

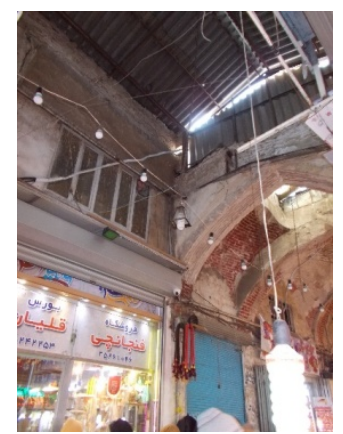

Figure 7. Part 1-Camera 3: Shahidi-Rasta-Bazari 03/2016

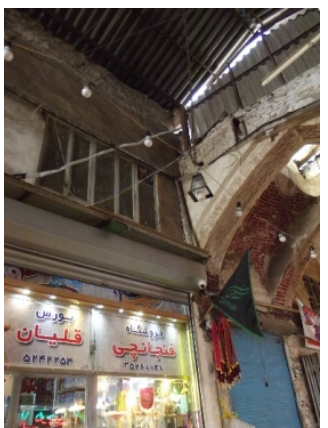

Figure 8. Part 1-Camera 3: Shahidi-Rasta-Bazari 11/2017

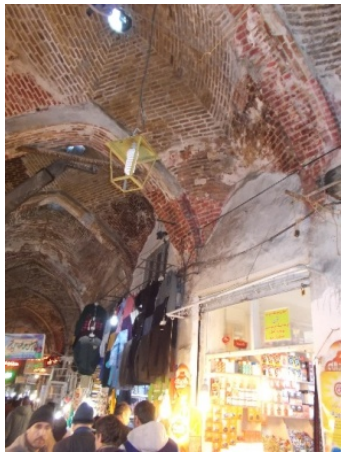

Figure 9. Part 1-Camera 4: Shahidi-Rasta-Bazari 03/2016

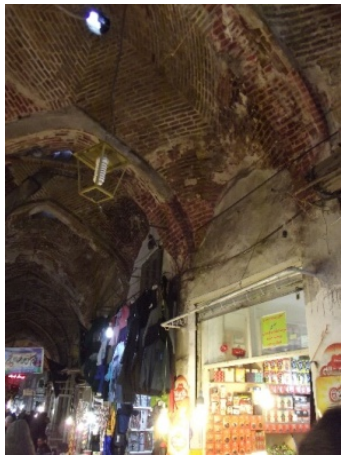

Figure 10. Part 1-Camera 4: Shahidi-Rasta-Bazari 11/2017

\subsection{Surface Contamination and Darkness of the Surface Materials}

The smoke of cigars, polluted environment in this region, firing as a result of the area's wearing out condition cause darkness, getting layered and traces of salty layer on the ceiling of the entrance dome [9].

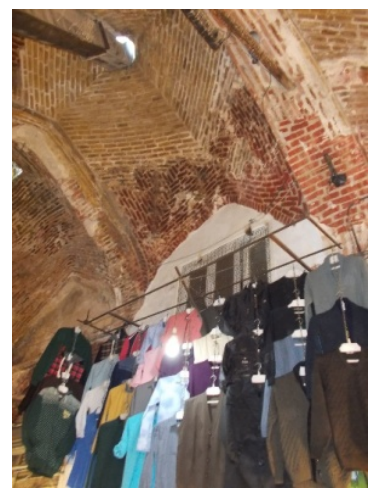

Figure 11. Part 1-Camera 5: Shahidi-Rasta-Bazari 03/2016

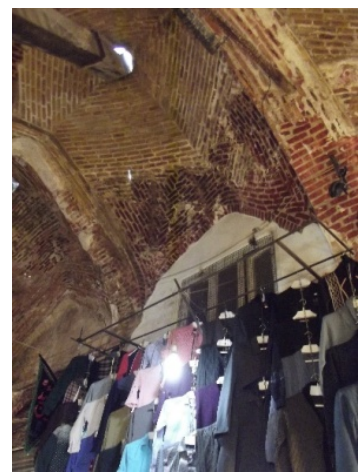

Figure 12. Part 1-Camera 5: Shahidi-Rasta-Bazari 11/2017 
A rise in some part of the dome vault: this damage has been caused due to wearing out of the materials and pressures exerted on this section that it will collapse if it is not restored [9].

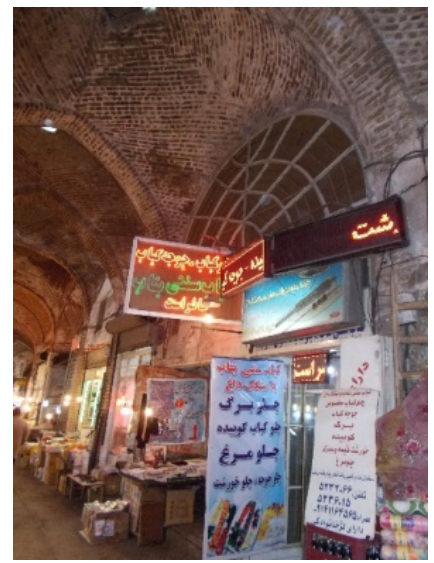

Figure 13. Part 1-Camera 6: Shahidi-Rasta-Bazari 03/2016

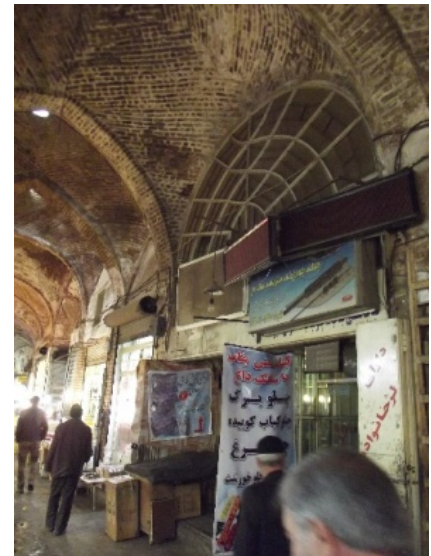

Figure 14. Part 1-Camera 6: Shahidi-Rasta-Bazari 11/2017

\subsection{Problems if Brick and Brickwork Structures}

One of the most common damages is the formation of salt layer in some sections resulted from penetration of the rain and water into the brickworks. This causes reduction of the mortar minerals in the brickwork appeared as salt layers. Extrusion and removing of some part of the façade due to pressure of internal forces causes collapse in some sections. Natural factors such as raining and snowing humidity, earthquake and biologic factors also lead to much more damages in the monument [9].

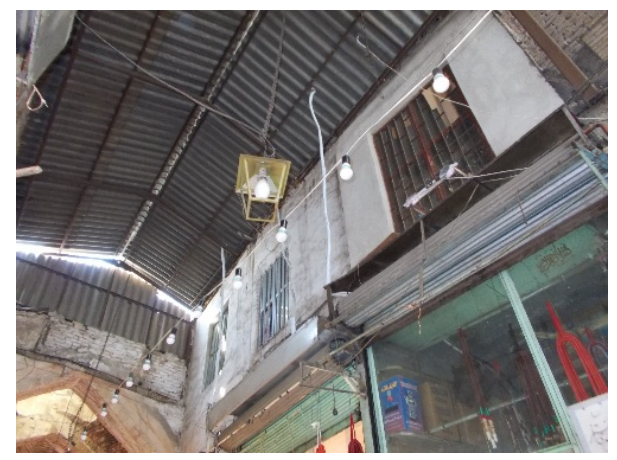

Figure 15. Part 1-Camera 7: Shahidi-Rasta-Bazari 03/2016

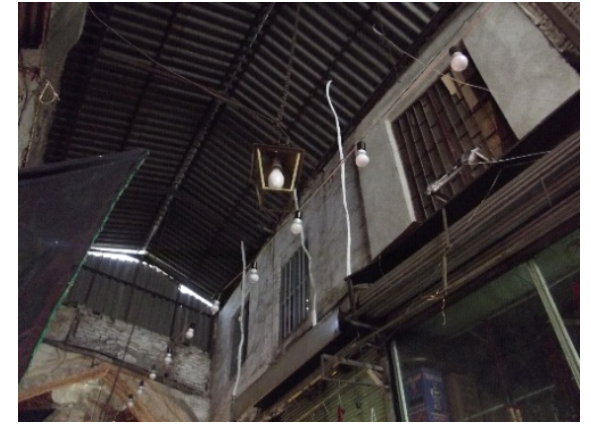

Figure 16. Part 1-Camera 7: Shahidi-Rasta-Bazari 11/2017

Temperature fluctuations: the materials' volume is increased due to heat and they return to primary state after removing this factor. Cold acts inversely. The change in the volume, as a result of contraction and expansion, causes cracks. This phenomenon is severe in the region with arid climate [9].

\subsection{Foundation Subsidence Resulted from the Weakness of the Foundation}

The foundation is usually weak in the old buildings and there is no possibility to transfer load to the ground uniformly, so this trend causes cracks and destruction of the building due to secondary misbalance [9].

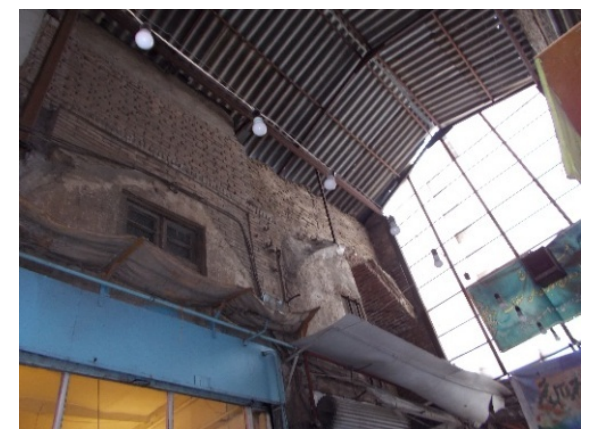

Figure 17. Part 1-Camera 8: Shahidi-Rasta-Bazari 03/2016

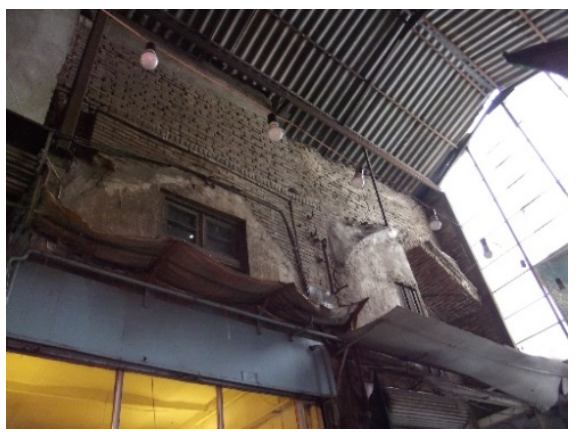

Figure 18. Part 1-Camera 8: Shahidi-Rasta-Bazari 11/2017

\subsection{Foundation Subsidence Due to the Building Volume Changes}

Changes in the different sections of the building are done due to changes in the volume of mortars after primary drying of humidity and weakness of the some structural sections including load bearing vaults on the coverings and since this phenomenon has a negative effect on standard load transfer of building weight, in most cases, it causes some cracks in the building [9]. 


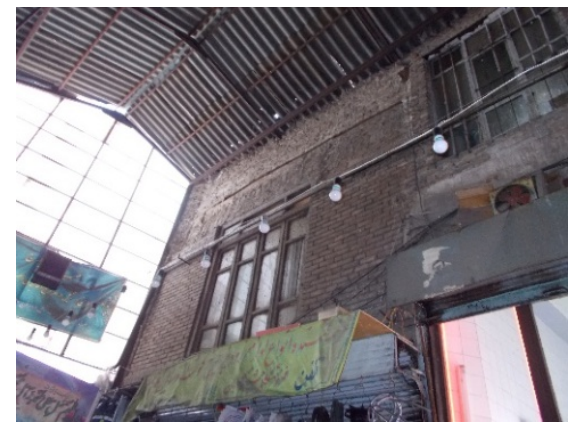

Figure 19. Part 1-Camera 9: Shahidi-Rasta-Bazari 03/2016

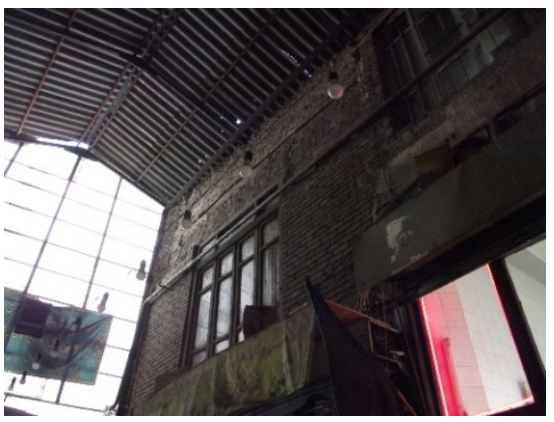

Figure 20. Part 1-Camera 9: Shahidi-Rasta-Bazari 11/2017

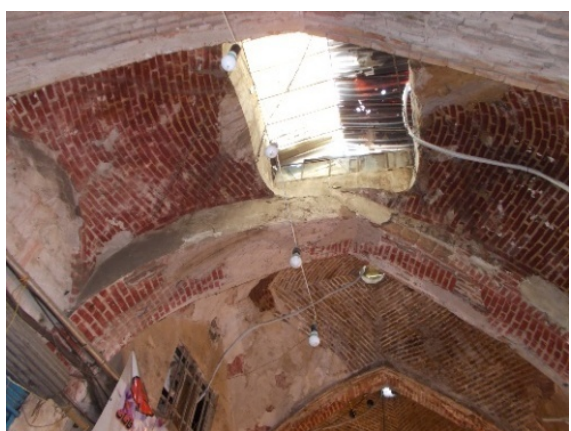

Figure 21. Part 1-Camera 10: Shahidi-Rasta-Bazari 03/2016

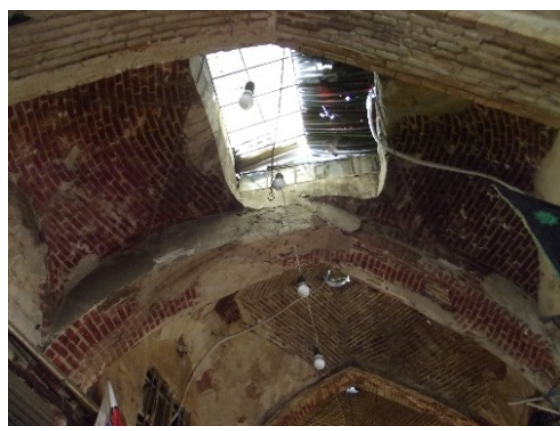

Figure 22. Part 1-Camera 10: Shahidi-Rasta-Bazari 11/2017

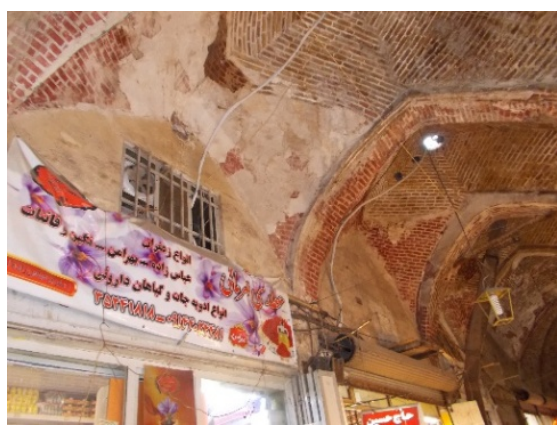

Figure 23. Part 1-Camera 11: Shahidi-Rasta-Bazari 03/2016

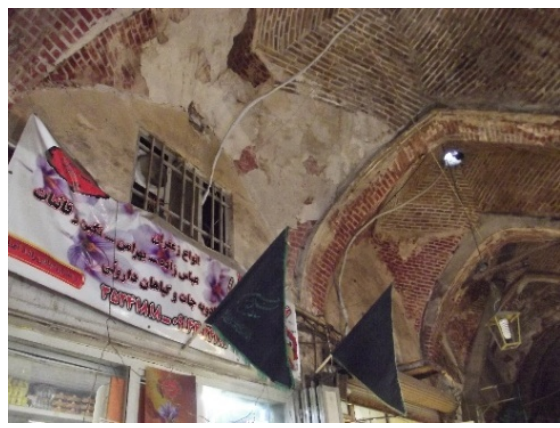

Figure 24. Part 1-Camera 11: Shahidi-Rasta-Bazari11/2017

Table 2. Damages of Shahidi-Rasta-Bazari (Techniques and experiences of the cities' historic fabric planning, Kalantaripour, Ahmad) and Twelve lessons of restoration, Mohammad Moradi, and Moheb Ali, 2014)

\begin{tabular}{|c|c|c|c|c|}
\hline Damages & Imbalance & Destructive factors & Treatment approximation & Explanation \\
\hline Humidity, corrosion & $\begin{array}{l}\text { Penetration of humidity } \\
\text { and increase of wearing } \\
\text { out }\end{array}$ & $\begin{array}{l}\text { Improper systems for } \\
\text { removing humidity, } \\
\text { climatic and environmental } \\
\text { conditions }\end{array}$ & $\begin{array}{l}\text { Organizing the disposal of } \\
\text { rainfalls, controlling and } \\
\text { removing of increasing } \\
\text { humidity }\end{array}$ & $\begin{array}{l}\text { Using appropriate methods } \\
\text { for prevention of humidity }\end{array}$ \\
\hline $\begin{array}{l}\text { Surface contamination } \\
\text { in the domes of entrance } \\
\text { corridors }\end{array}$ & & Environmental pollution & $\begin{array}{l}\text { Removing surface pollution } \\
\text { and cleaning }\end{array}$ & \\
\hline Visual disorders & & $\begin{array}{l}\text { Heterogeneity of the } \\
\text { materials, human physical } \\
\text { factors }\end{array}$ & $\begin{array}{l}\text { Collecting all extra equipment } \\
\text { and installation in an } \\
\text { appropriate section }\end{array}$ & \\
\hline $\begin{array}{l}\text { Corrosion of materials, } \\
\text { tracks resulted from } \\
\text { foundation subsidence }\end{array}$ & Humidity penetration & $\begin{array}{l}\text { Climatic condition, } \\
\text { removing rainfall }\end{array}$ & Covering insulation & $\begin{array}{l}\text { Using appropriate ceiling } \\
\text { covering }\end{array}$ \\
\hline $\begin{array}{l}\text { deformation of Wall } \\
\text { tracks }\end{array}$ & Extra load & $\begin{array}{l}\text { Structure changes, oldness } \\
\text { of materials }\end{array}$ & Strengthening and lightening & $\begin{array}{l}\text { Creation of conditions for } \\
\text { reduction of extra load }\end{array}$ \\
\hline $\begin{array}{l}\text { Improper flooring of the } \\
\text { passages and quality of } \\
\text { the flooring }\end{array}$ & $\begin{array}{l}\text { Transportation and } \\
\text { humidity }\end{array}$ & $\begin{array}{l}\text { Human factors, removing } \\
\text { surface water }\end{array}$ & $\begin{array}{l}\text { Proper flooring and } \\
\text { establishment of the spaces for } \\
\text { collecting surface water }\end{array}$ & \\
\hline $\begin{array}{l}\text { Destructing surface } \\
\text { materials and smoke }\end{array}$ & Firing & $\begin{array}{l}\text { Human factors, electrical } \\
\text { cables }\end{array}$ & $\begin{array}{l}\text { Organizing the cables, } \\
\text { equipping fire extinction } \\
\text { systems and cleaning }\end{array}$ & \\
\hline $\begin{array}{l}\text { Collapse, fracture of the } \\
\text { materials }\end{array}$ & $\begin{array}{l}\text { Human and social } \\
\text { destructive factors }\end{array}$ & $\begin{array}{l}\text { Mismanagement of } \\
\text { monument maintenance }\end{array}$ & $\begin{array}{l}\text { Mismanagement of monument } \\
\text { maintenance }\end{array}$ & \\
\hline
\end{tabular}




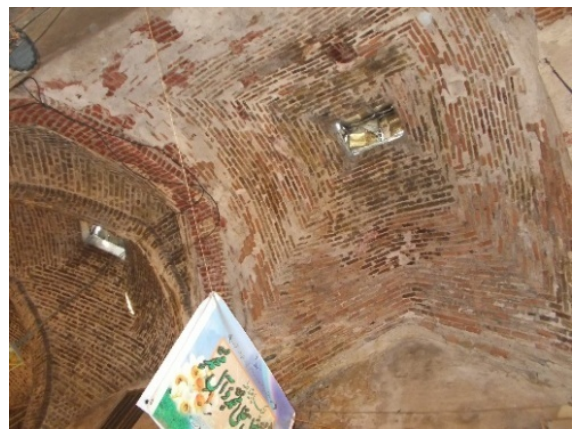

Figure 25. Part 1-Camera 12: Shahidi-Rasta-Bazari 03/2016

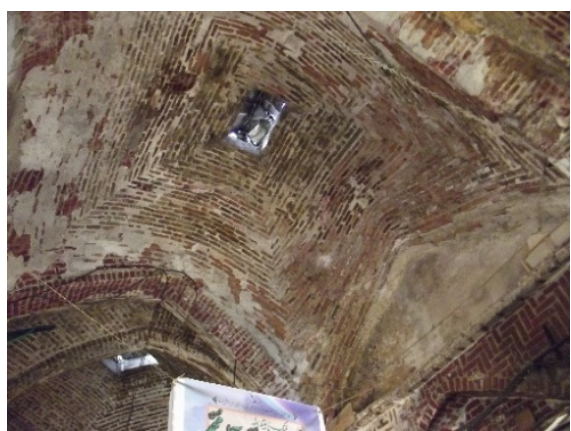

Figure 26. Part 1-Camera 12: Shahidi-Rasta-Bazari 11/2017

Regarding the cracks of this building, it should be noted that when humidity penetrates in cracks, algae and fungi grow there and also freezing and increase of the water volume cause rapid destruction $[5,6]$.

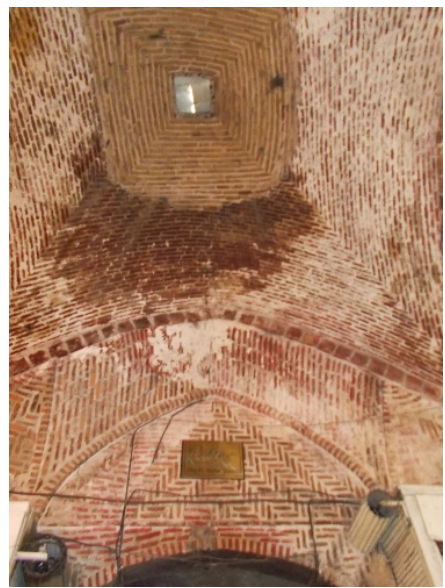

Figure 27. Part 2-Camera 1: Shahidi-Rasta-Bazari 03/2016

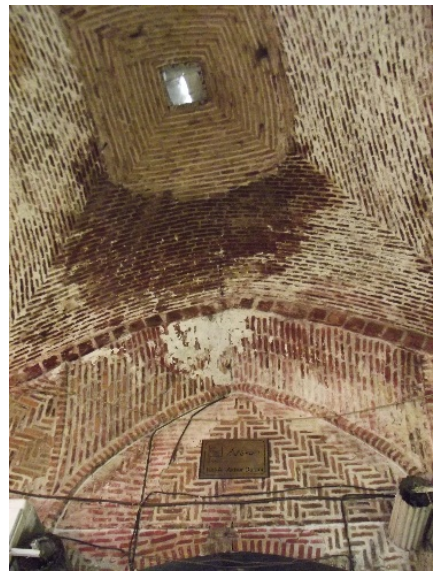

Figure 28. Part 2-Camera 1: Shahidi-Rasta-Bazari 11/2017
Existence of the biological damages in the district and the factors causing formation of mold and fungus on the walls are among the other recognized factors $[5,6]$.

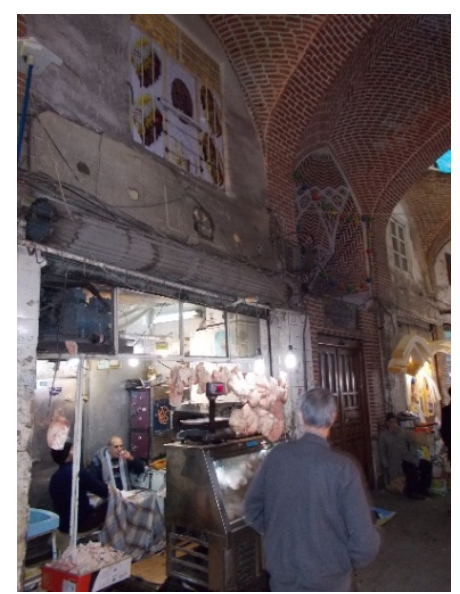

Figure 29. Part 2-Camera 2: Shahidi-Rasta-Bazari 03/2016

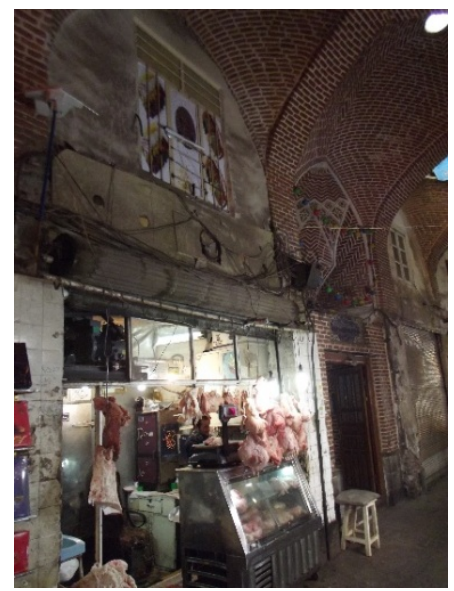

Figure 30. Part 2-Camera 2: Shahidi-Rasta-Bazari 11/2017

\subsection{Foundation Subsidence Resulted from Changes in the Beneath Layers of the Ground}

Weakness of the substrate soil granulation in the region and also displacement of the underground water beds and creation of vacant holes resulted from decreasing humidity are the main factors leading to foundation subsidence $[5,6]$.

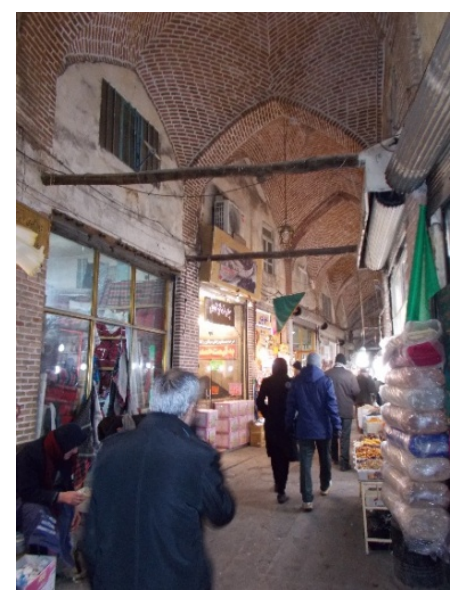

Figure 31. Part 2-Camera 3: Shahidi-Rasta-Bazari 03/2016 


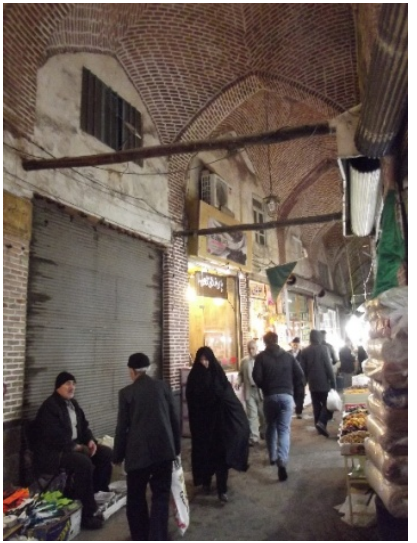

Figure 32. Part 2-Camera 3: Shahidi-Rasta-Bazari 11/2017

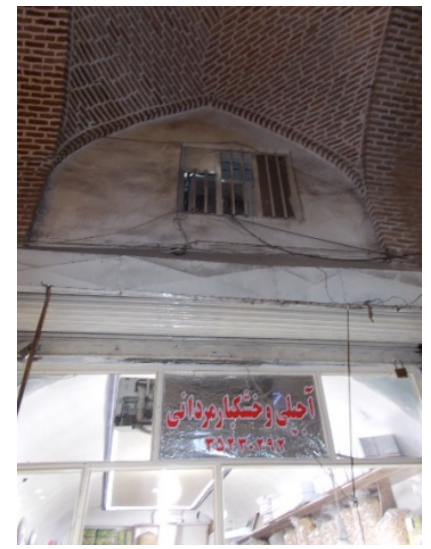

Figure 33. Part 2-Camera 4: Shahidi-Rasta-Bazari 03/2016

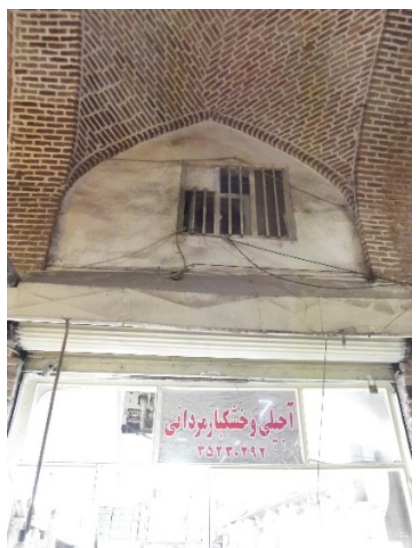

Figure 34. Part 2-Camera 4: Shahidi-Rasta-Bazari 11/2017

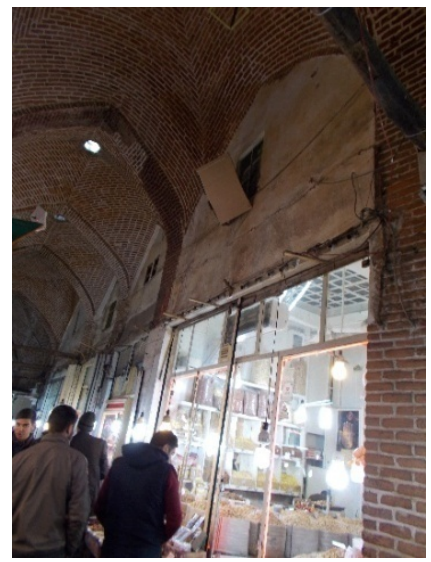

Figure 35. Part 2-Camera 5: Shahidi-Rasta-Bazari 03/2016

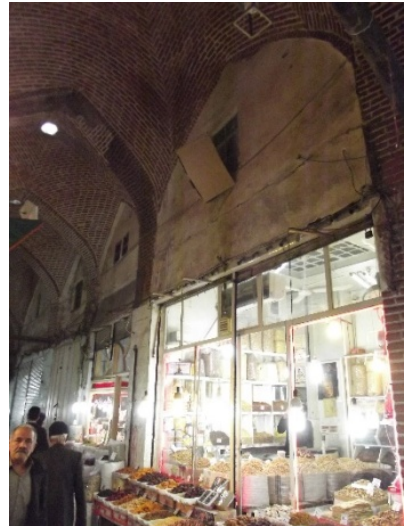

Figure 36. Part 2-Camera 5: Shahidi-Rasta-Bazari 11/2017

The ground layers' displacement, due to rapid factors, including earthquake and strong winds, cause big cracks in the old buildings which sometimes lead to separating two layers. This damage can obviously be seen in the monument façade $[5,6]$.

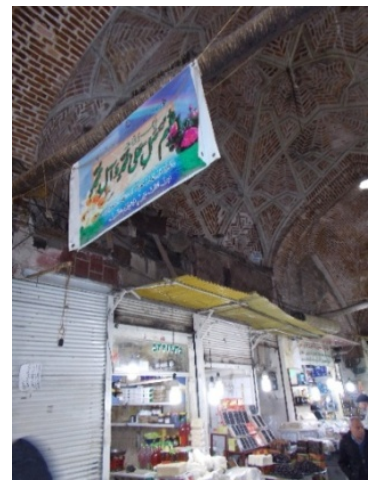

Figure 37. Part 2-Camera 6: Shahidi-Rasta-Bazari 03/2016

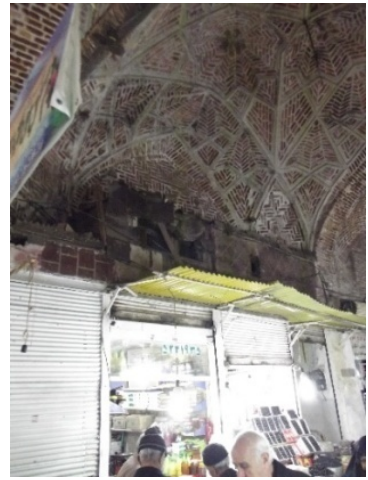

Figure 38. Part 2-Camera 6: Shahidi-Rasta-Bazari 11/2017

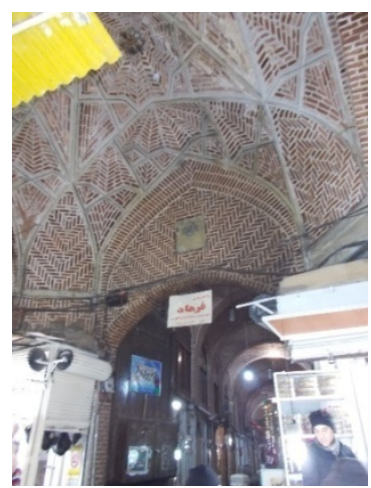

Figure 39. Part 2-Camera 7: Shahidi-Rasta-Bazari 03/2016 


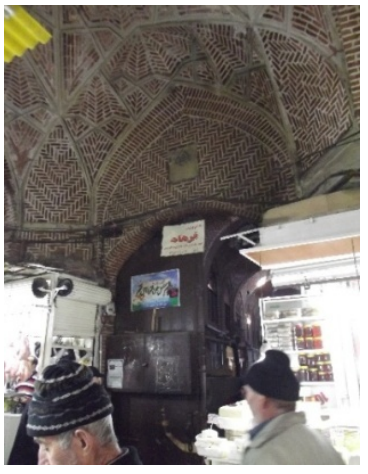

Figure 40. Part 2-Camera 7: Shahidi-Rasta-Bazari 11/2017

Of other destructive quality of water in the polluted areas is this fact that this condition facilitates harmful chemical reactions. For example, the air pollution can be seen as CO2 that is emitted by burning the fuels in the automobiles and it is toxic. When the air relative humidity is increased, the rainwater is combined with $\mathrm{CO} 2$ and converted to carbonic acid that is a corrosive acid and leads to corrosion of the materials and their collapse $[5,6]$.

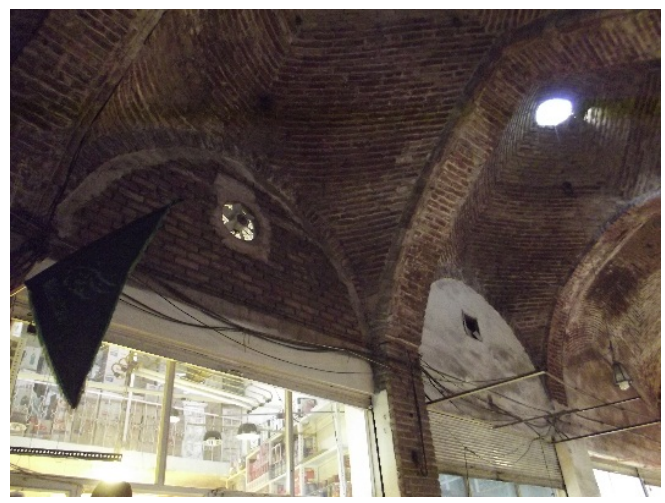

Figure 41. Part 2-Camera 8: Shahidi-Rasta-Bazari 11/2017

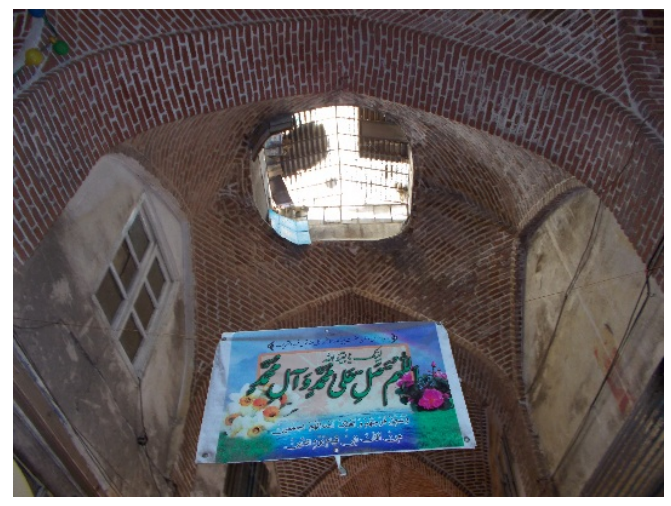

Figure 42. Part 2-Camera 9: Shahidi-Rasta-Bazari 11/2017

Installations' wearing out (electricity, communications, cooling and heating, security) leading to damages in this site which requires renovation $[5,6]$.

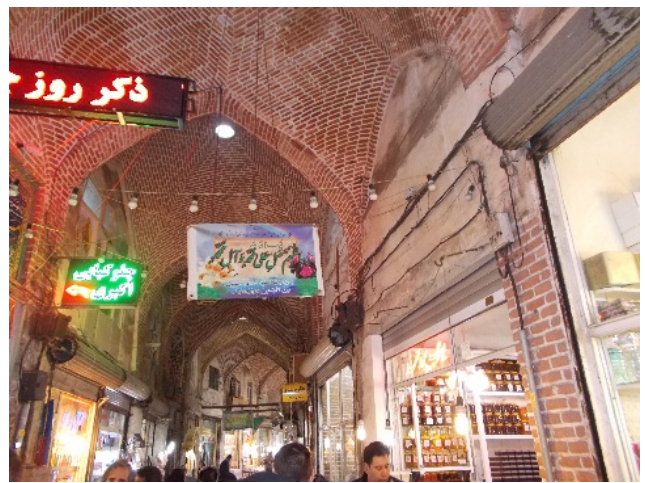

Figure 43. Part 2-Camera 10: Shahidi-Rasta-Bazari 03/2016

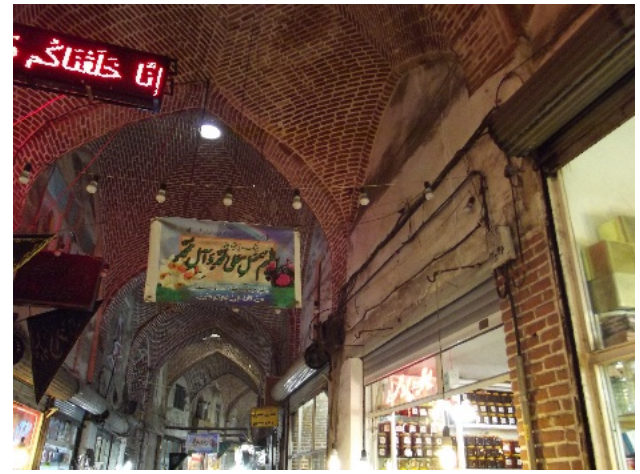

Figure 44. Part 2-Camera 10: Shahidi-Rasta-Bazari 11/2017

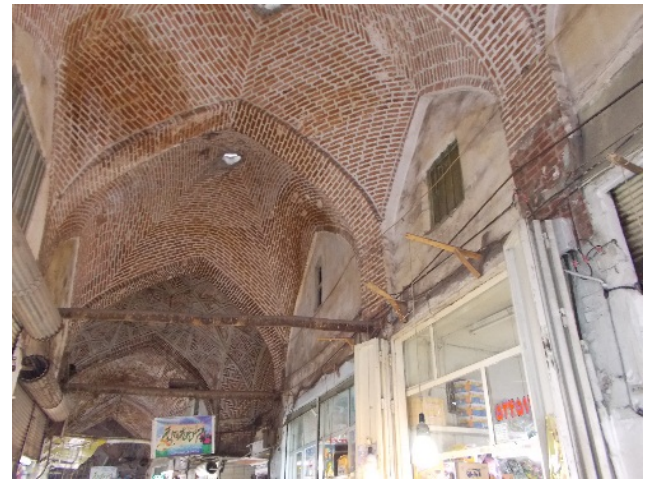

Figure 45. Part 2-Camera 11: Shahidi-Rasta-Bazari 03/2016

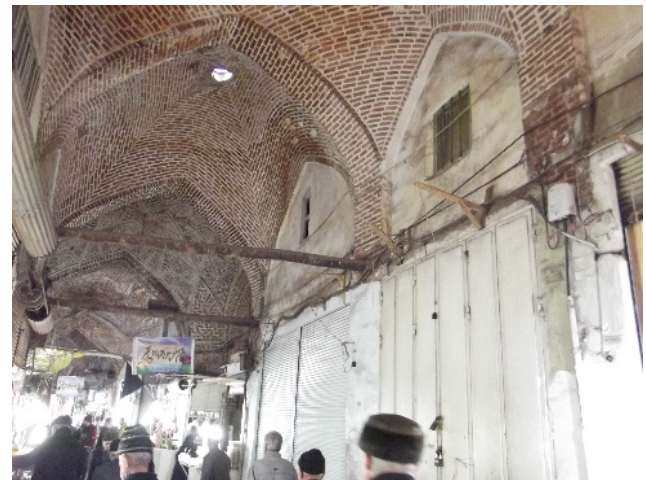

Figure 46. Part 2-Camera 11: Shahidi-Rasta-Bazari 11/2017

Table 3. Etiology of Shahidi-Rasta-Bazari $[5,6]$

\begin{tabular}{|l|l|l|l|}
\hline Damages & Imbalance & Descriptive factor & Treatment \\
\hline Corrosion of the walls & $\begin{array}{l}\text { Fracture and } \\
\text { corrosion of materials }\end{array}$ & $\begin{array}{l}\text { Increasing and decreasing level of } \\
\text { humidity and improper insulation }\end{array}$ & Roof insulation \\
\hline $\begin{array}{l}\text { Utilization of the brick on the former } \\
\text { mortar covering and removing bricks } \\
\text { from the walls }\end{array}$ & Corrosion & $\begin{array}{l}\text { Using materials with different } \\
\text { expansion coefficient }\end{array}$ & Sloping the Saraye \\
\hline
\end{tabular}




\begin{tabular}{|l|l|l|l|}
\hline Damages & Imbalance & Descriptive factor & Treatment \\
\hline Dandruff on the wall & & Human factors & Floor leveling \\
\hline $\begin{array}{l}\text { Cracking besides white masses in the } \\
\text { location of cracking }\end{array}$ & $\begin{array}{l}\text { The monument age and low } \\
\text { quality of materials } \\
\text { Application of the cement coating in } \\
\text { repaired places }\end{array}$ & $\begin{array}{l}\text { Mechanical pressure related to } \\
\text { increase of the lime volume } \\
\text { (related to cracks) }\end{array}$ & $\begin{array}{l}\text { Cleaning toilets and transfering them to the } \\
\text { and wain place }\end{array}$ \\
\hline $\begin{array}{l}\text { Removing the façade decorations } \\
\text { Piling of the garbage }\end{array}$ & $\begin{array}{l}\text { The plaster carbonated salts and } \\
\text { loam }\end{array}$ & Repairing the decorations \\
\hline & & $\begin{array}{l}\text { Penetration of the pollutants } \\
\text { thorough surface fabric (darkness } \\
\text { of the materials) }\end{array}$ & Repairing of plastering of the shops \\
\hline & Improper piping & Suction in the foot of the wall & Replacing old materials \\
\hline
\end{tabular}

Table 4. Corridor etiology [5,6]

\begin{tabular}{|l|l|l|l|}
\hline \multicolumn{1}{|c|}{ Damages } & \multicolumn{1}{|c|}{ Imbalance } & \multicolumn{1}{c|}{ Descriptive factor } \\
\hline $\begin{array}{l}\text { Walls corrosion and their wearing } \\
\text { out quality }\end{array}$ & Fracture and corrosion of materials & Fracture and corrosion of materials & Repairing of the walls' plastering \\
\hline Heterogeneous flooring & Corrosion & Improper restoration & Floor sloping \\
\hline $\begin{array}{l}\text { Application of cement covering in } \\
\text { the repaired sections }\end{array}$ & & Plaster carbonated salt and loam & Floor leveling \\
\hline $\begin{array}{l}\text { Cracking with white mass in the } \\
\text { cracked places }\end{array}$ & & $\begin{array}{l}\text { The monument age and low quality } \\
\text { materials }\end{array}$ & $\begin{array}{l}\text { Organizing electrical installations } \\
\text { and water piping and removing } \\
\text { them from façade and wall }\end{array}$ \\
\hline & $\begin{array}{l}\text { Mechanical pressure related to } \\
\text { increase of the loamy grains } \\
\text { volume(related to cracks) }\end{array}$ & High temperature difference & Replacing old materials \\
\hline
\end{tabular}

Table 5. Etiology of shops [5,6]

\begin{tabular}{|l|l|l|l|}
\hline Damages & Imbalance & Descriptive factor & Treatment \\
\hline $\begin{array}{l}\text { Walls corrosion and wearing } \\
\text { out }\end{array}$ & $\begin{array}{l}\text { Fracture and corrosion of } \\
\text { materials }\end{array}$ & $\begin{array}{l}\text { Increasing and decreasing level of } \\
\text { humidity and proper insulation }\end{array}$ & Collecting garbage and separating the clothes \\
\hline Formation of salt layers & Corrosion & Improper restoration & Drying the wet walls \\
\hline $\begin{array}{l}\text { Using cement covering in the } \\
\text { repaired sections }\end{array}$ & $\begin{array}{l}\text { Using materials with different } \\
\text { expansion coefficient }\end{array}$ & Floor leveling \\
\hline $\begin{array}{l}\text { Cracking along with white } \\
\text { mass in the cracked places }\end{array}$ & $\begin{array}{l}\text { Mechanical pressure related to } \\
\text { increase of the lime volume(related } \\
\text { to cracks) }\end{array}$ & $\begin{array}{l}\text { Organizing electrical installations and water } \\
\text { wiping and removing them from façade and the } \\
\text { wall }\end{array}$ \\
\hline $\begin{array}{l}\text { Collecting garbage and the } \\
\text { clothes }\end{array}$ & $\begin{array}{l}\text { The monument age and low quality } \\
\text { of materials }\end{array}$ & $\begin{array}{l}\text { Cleaning toilets and transferring to the main } \\
\text { place }\end{array}$ \\
\hline heterogeneous flooring & High temperature difference & Replacing old materials \\
\hline & Carbonated salts, plaster and loam & Suction in the foot of the wall \\
\hline & Human factors & Removing cement covering \\
\hline
\end{tabular}

\section{Conclusion}

According to the mentioned damages in the historic buildings, in the cases of happing disasters, including earthquake, flooding and etc. this area is one of the high risk areas in Tabriz that requires management.

It is essential to identify the different compounds used in the restoration phase and gain information by field studies and comparison of the different buildings.
Lack of administrative stability has led to this condition and none of the studies, which carried out with high cost, have had fruitful results. The reason is changing administrative policies and lack of comprehensive policies which has led to incomplete projects. Basically, the employer or the governmental section lack academic and technical definition tools and on other hand, the documents lack administrative capability and the plans were just wasting the time and cost. 
Credits in the support of the valuable buildings and fabrics in the historic area of bazaar.

The discussed area encounters with high risks. According to the area soil condition and examining the measures, this fabric is considered a high risk building.

The slopes should be implemented so that it can prevent the penetration of the surface water to the foundation and the district via proper draining. According to existence of the canals in the studied area, examining the exact location during the operation is essential. The canals, wells and Sewage wells adjacent to the location of the construction can be dangerous. Some cases, including the collapse of the old wells and canals, Sewage wells of the old buildings cause considerable foundation subsidence and reduction of the loading capacity.

Injection of concrete beneath the foundations and construction of the secondary wells and filling the well with concrete can be carried out for empowering the foundations.

In the case of proposing the strengthening and repairing methods and designs, after complementary examination and observation of any hole under the foundation to one and a half times the width, a proper method can be used for repairing, restoration and filling the holes with concrete.

There must be a skilled geotechnic engineer in each operation in the historic district.

It is recommended to use light materials, including brick and composite, for renovation of the facade of the bazaar corridor, reduction of the exerted load on the old structure, prevention of the sudden subsidence and strengthen the structure.

Renovation of the installation (electricity, communications, heating and cooling systems) in the historic buildings is one of the important factors for controlling the disaster in the historic places.

Nowadays, the temperature fluctuations can be minimized by installation of the expansion seal in the standard intervals and this method can be used in renovation and rehabilitation of the buildings.

The visual organization of the wall and its strengthening should be considered in this section.
Cleaning and strengthening the entrance domes, having historical value, is one of the goals of this renovation.

As it was mentioned, architectural restoration is a branch of architecture that restores the historic spaces from structural and functional perspective, according to the identification and investigation of the historic texture and buildings. The buildings in the texture are important in terms of identity and the manifestation of beliefs, cultures, behaviors and social relations. One of the most important reasons for restoration is preservation of values, including the building, construction period and architect. The level of importance differs in different buildings. Restoration is not done for buildings of a specific period. There are buildings in the texture that are important due to representing the identity, culture, beliefs, behaviors and social relations and they can play a major role in the continuity of a memory. Hence, after a short definition of restoration and its importance Shahidi-Rasta-Bazari located in the Tabriz Bazaar was studied and then the damages and their reasons were investigated. Finally, the solutions were proposed.

\section{References}

[1] Mohammad Mansour Falamaki, Formation of architecture in Iran and west experiences, Faza press, Tehran, 2012, $1^{\text {st }}$ edition.

[2] Geographical organization of Military forces, Social geography in Tabriz geographical glossary, Geographical organization of Military forces, Tehran, 2011, $1^{\text {st }}$ edition.

[3] Islamic world encyclopedia, reviewed on $11^{\text {th }}$ of August, 2010.

[4] Jame-Jam newspaper, No.1114, 6 ${ }^{\text {th }}$ April 2004.

[5] Ahmad Pour Ahmad, Hossein Kalantari Khalil Abad, Masoud Kalantari Khalil Abad, Techniques and experiences of the cities' historic fabrics planning, Jahad Daneshghai Press, Tehran, 2006.

[6] Asghar Mohammad Moradi, Mohammad hasan Moheb Ali, Twelve lessons of restoration, Tosehe Iran press, Tehran, 2010.

[7] Behrouz Khamachi, My city of Tabriz, Nedaye Shams, Tabriz, reviewed on 30 ${ }^{\text {th }}$ of September 2015.

[8] Hossein Soltanzadeh, Bazaars in Iran cities, Office of Cultural Research press, Tehran, 2001.

[9] Mohammad Taghizadeh, The Islamic architecture and urban building theoretical principles, Rahiyan press, Tehran, 2006. 